\title{
Perbandingan Sistem Pendingin pada Konsentrasi Water Coolant, Air Mineral, dan Air Laut Menggunakan Panel Surya Fleksibel Monocrystaline 20 Wp
}

\author{
Deni Almanda 1 , Budiman Putra Piliang 2 \\ 1) 2) Teknik Elektro Universitas Muhammadiyah Jakarta \\ Jl. Cempaka Putih Tengah 27 No 47 \\ Email: ${ }^{1)}$ deni.almanda@ftumj.ac.id, 2) 2012420043@ftumj.ac.id
}

\begin{abstract}
ABSTRAK
Energi matahari dimanfaatkan sebagai sumber energi alternatif yang potensial, terutama dilihat dari sumbernya yang memancarkan energi yang sangat besar serta waktunya yang panjang. Selain itu diharapkan energi matahari dapat dimanfaatkan sebagai sumber energi listrik yang ramah lingkungan, sehingga apabila energi ini dapat dikelola dengan baik, diharapkan kebutuhan masyarakat akan energi dapat terpenuhi. Panel surya bisa ditingkatkan efisiensinya dengan cara menambahkan reflektor atau konsentrator. Reflektror atau konsentrator pada panel sel surya berbentuk seperti cermin yang difungsikan sebagai pemantul dan pemfokus cahaya matahari ke panel sel surya. Pemantulan cahaya Pemantulan cahaya matahari ini akan membuat intensitas cahaya matahari lebih terkonsentrasi pada panel sel surya sehingga energi listrik yang di keluarkan panel sel surya menjadi semakin besar. Peningkatan daya keluaran pada panel sel surya ini akan meningkat menjadi sekitar 46\%. Dari hasil pengujian dan analisa dengan simulasi pencahayaan matahari langsung pada Panel Surya Fleksibel dengan sudut 0 derajat menggunakan Sistem Pendingin Water Coolant, Air Mineral, Air Laut didapatkan efisiensi sebesar 15.41\%, sedangkan menggunakan system pendingin Air Mineral sebesar 14.45\%, dan menggunakan system pendingin Air Laut Sebesar 13.50\%. Pengujian Efisiensi Panel Surya Fleksibel pada Sudut 25 Derajat pada penyinaran matahari langsung menggunakan system pendingin Water Coolant sebesar 14.74\%, sedangkan menggunakan system pendingin Air Mineal sebesar 14.01\%, dan menggunakan system pendingin Air Laut sebesar 13.06\%
\end{abstract}

Kata Kunci : Panel Surya Fleksibel, Efisiensi Panel Surya Fleksibel, Water Coolant, Air Mineral, Air Laut.

\section{PENDAHULUAN}

Energi matahari dimanfaatkan sebagai sumber energi alternatif yang potensial, terutama dilihat dari sumbernya yang memancarkan energi yang sangat besar serta waktunya yang panjang. Selain itu diharapkan energi matahari dapat dimanfaatkan sebagai sumber energi listrik yang ramah lingkungan, sehingga apabila energi ini dapat dikelola dengan baik, diharapkan kebutuhan masyarakat akan energi dapat terpenuhi. Indonesia sebagai negara tropis memiliki kelebihan pada sinar matahari [1]. Mengurangi ketebalan wafer silikon kristalin merupakan tujuan utama industri [2]. Listrik merupakan bentuk energi yang paling luas digunakan [3]. Listrik merupakan suatu kebutuhan yang penting bagi kehidupan orang banyak [4]. Fotovoltaik Seluler adalah sebuah teknologi yang dapat memenuhi kebutuhan ini dengan memanfaatkan teknologi fotovoltaik fleksibel [5]. Sel surya polimer dapat diproses dari solusi atau dispersi yang menawarkan potensi teknologi yang penting untuk pembuatan dengan biaya rendah pada area besar dan substrat fleksibel [6]. Panel surya merupakan device yang sudah sempurna untuk diaplikasikan sebagai PLTS [7].
Sel surya adalah sebuah elemen semikonduktor yang dapat mengkonversi energy surya menjadi energy listrik dengan prinsip fotovoltaik. Modul surya adalah kumpulan beberapa sel surya, dan panel surya adalah kumpulan beberapa modul surya. Intensitas radiasi cahaya matahari yang diterima sel surya sebanding dengan tegangan dan arus listrik yang dihasilkan oleh sel surya, sedangkan apabila suhu lingkungan semakin tinggi dengan intensitas radiasi cahaya matahari yang tetap, maka tegangan panel surya akan berkurang dan arus listrik yang dihasilkan akan bertambah. Perubahan temperatur sel-sel surya ini diakibatkan oleh temperatur, kondisi awan dan kecepatan angin di lingkungan sekitar daerah penempatan panel surya.

Panel surya bisa ditingkatkan efisiensinya dengan cara menambahkan reflektor atau konsentrator. Reflektror atau konsentrator pada panel sel surya berbentuk seperti cermin yang difungsikan sebagai pemantul dan pemfokus cahaya matahari ke panel sel surya. Pemantulan cahaya Pemantulan cahaya matahari ini akan membuat intensitas cahaya matahari lebih terkonsentrasi pada panel sel surya sehingga energi listrik yang di keluarkan panel sel surya menjadi semakin besar. Peningkatan daya keluaran pada panel sel surya ini akan meningkat 
menjadi sekitar 46\%. Meskipun penambahan reflektor atau konsentrator pada panel sel surya dapat menambah performa panel sel surya, tetapi teknik ini ternyata juga memiliki kelemahan. Akibat dari pengonsentrasian intensitas cahaya ini adalah berimbas pada temperatur panel sel surya yang akan meningkat cepat. Peningkatan temperatur ini dapat berpengaruh pada daya keluaran yang dihasilkan panel sel surya. Setiap kenaikan temperatur panel surya $1{ }^{\circ} \mathrm{C}$ (dari $25^{\circ} \mathrm{C}$ ). Akan mengakibatkan berkurangnya sekitar $0,5 \%$ pada total tenaga yang dihasilkan. Dalam hal ini system pendingin tersebut mengurangi tingkat kepanasan pada panel surya dan meningkatkan efisiensi tegangan yang masuk pada pendingin pada panel surya. Dihunian yang modern saat ini, tak sedikit pula rumah yang memiliki kamera cctv untuk mendukung keamanan rumahnya [8]. PLTH ini dioperasikan untuk memikul beban [9]. Energi menjadi salah satu isu yang dihadapi oleh Indonesia saat ini bahkan dunia, karena ketidakseimbangan antara ketersediaan energi dengan kebutuhanya [10]. Kemajuan teknologi yang pada masa sekarang ini terus mengalami perkembangan dan di ikuti oleh sebagian bahkan hampir semua kalangan [11]. Didalam sistem jaringan distribusi listrik lokal (local grid) yang kita mengenal istilah microgrid dan nanogrid yang terkenal untuk pembangkit listrik yang berdiri sendiri [12]. Teknik elektro merupakan salah satu dari ilmu teknik dasar yang merupakan komponen esensial dari perkembangan ilmu pengetahuan alam dan teknologi [13]. Transistor film tipis organik memiliki potensi untuk penggunaan pada aplikasi elektronika yang biayanya rendah, permukaannya luas, ringan dan fleksibel [14]. Arduino berfungsi membaca nilai pada sensor tegangan AC, sensor tegangan DC, LCD [15]. Ada banyak sumber energi terbarukan seperti energi air, energi angin dan energi matahari [16]. Perkembangan dibidang ilmu pengetahuan dan teknologi memiliki kemajuan yang sangat pesat yang berdampak pada kehidupan kita saat ini[17]. Energi listrik merupakan salah satu kebutuhan pokok yang sangat penting dalam kehidupan manusia saat ini, hampir semua aktifitas manusia berhubungan dengan energi listrik [18]. Rangkaian band pass filter adalah rangkaian yang mengizinkan lewat sinyal yang memiliki frekuensi pada rentang tertentu dan mengattenuasikan sinyal yang memiliki frekuensi di luar rentang tersebut [19]. Rangkaian penyearah gelombang penuh adalah penyearah yang mengonversikan kedua siklus positif dan negative dari sinyal AC menjadi sinyal DC yang berdenyut [20]. Iradiasi surya biasanya diukur dengan solarimeter yang ditempatkan pada permukaan datar [21]. Energi sangat penting untuk manusia untuk bisa bertahan hidup [22]. Material organik telah menjadi perhatian para peneliti meskipun karakternya kurang dari silikon [23]. Security home adalah sebuah rumah yang didesain untuk menjaga kemanan rumah melalui perangkat keras maupun perangkat lunak untuk memberikan keamanan dari segi pintu, system alarm, detector gerak (passive infrared), detector api, gas, maupun air [24]. Perkembangan teknologi mendorong sektor industri untuk lebih kreatif dalam membuat sebuah alat sederhana yang dapat membantu masyarakat dalam kehidupan sehari-hari sehingga dapat berguna bagi banyak orang dan berfungsi baik [25]. Tegangan sirkuit terbuka akan bertambah jika sel sel surya dihubungkan secara seri [26]. Energi merupakan bagian yang paling penting bag makhluk hidup untuk bisa terus bertahan hidup [27]. Transistor efek medan berbasis semikonduktor organik bisa dimanfaatkan untuk sensor kelembaban[28]. Mengerjakan proyek tepat waktu sesuai dengan biaya, lingkup pekerjaan, serta mutu yang sudah ditetapkan menjadi target setiap perusahaan [29]. Salah satu bahan semikonduktor organik yang sering digunakan adalah pentacene karena ketersediaannya dan kinerja divaisnya [30]. Sumber energi fosil seperti minyak bumi, gas alam dan batubara akan bisa bertahan jika sumber energi terbarukan digunakan [31]. Sepeda motor merupakan kendaraan yang lazim digunakan oleh semua kalangan; mulai dari kalangan atas, menengah, sampai kalangan bawah [32]. Untuk dapat mendayai suatu beban listrik dengan baik, dalam hal ini merupakan rumah kaca, diperlukan desain sistem yang baik pula [33]. Hal ini yang melandasi penulis untuk merancang dan meneliti suatu penelitian yaitu

\section{"PERBANDINGAN SISTEM PENDINGIN} PADA KONSENTRASI WATER COOLANT, AIR MINERAL, DAN AIR LAUT MENGGUNAKAN PANEL SURYA FLEKSIBEL“. Dari hasil penelitian ini diharapkan bisa diketahui seberapa efisien penggunaan sistem pendingin photovoltaic tersebut.

\section{METODOLOGI}

Metodologi penelitian yang dilakukan dalam penelitian kali ini adalah dengan membandingkan Panel Surya Fleksibel yang diberi pendingin Water Coolant, Air Mineral, dan Air Laut dengan penyinaran matahari langsung. Nantinya tegangan dan suhu akan diambil sebagai data pembanding.

Dari hasil perbandingan tersebut nantinya akan dibandingkan data tegangan dan suhu. Tegangan dan suhu ini nantinya akan diperoleh efisiensi panel surya yang kemudian akan mempresentasikan Panel Surya Fleksibel menggunakan sistem pendingin Water Coolant, Air Mineral, dan Air Laut. 
RESISTOR (Elektronika Kendali Telekomunikasi Tenaga Listrik Komputer) Vol. 2 No. 2 e-ISSN : 2621-9700, p-ISSN : 2654-2684

Pengujian Perbandingan Efisiensi sistem pendingin Panel Surya Fleksibel menggunakan Water Coolant, Air Mineral, dan Air Laut pada Photovoltaic Fleksibel Jenis Monocrystalline $20 \mathrm{Wp}$ yang dihasilkan antar lain :

1. Menguji suhu permukaan panel surya dengan menggunakan termometer di setiap sisi saat terkena matahari dengan sistem pendingin dan tanpa pendingin.

2. Menguji suhu permukaan panel surya dengan menggunakan termometer di setiap sisi saat terkena matahari dengan sistem pendingin.

3. Intensitas tenaga surya yang dihasilkan oleh Panel Surya Fleksibel.

4. Tegangan dan arus yang dihasilkan oleh panel surya dengan menggunakan sistem pendingin Water Cooling, Air Mineral, dan Air Laut.

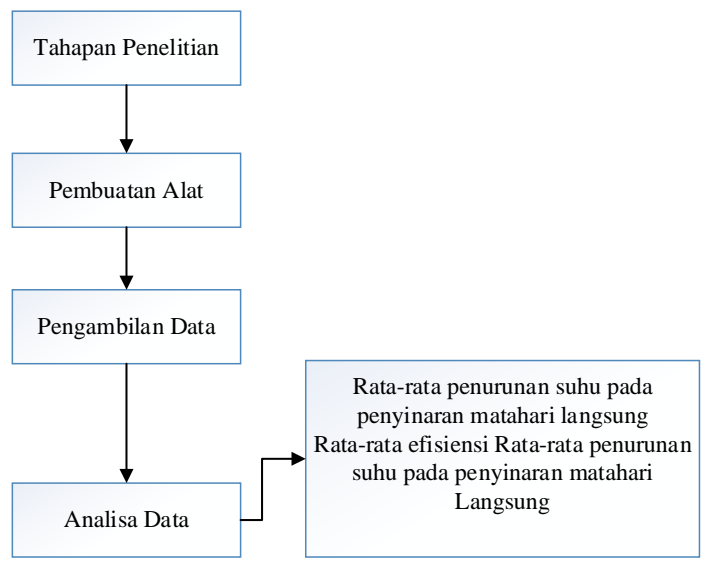

Gambar 1 Alur penelitian.
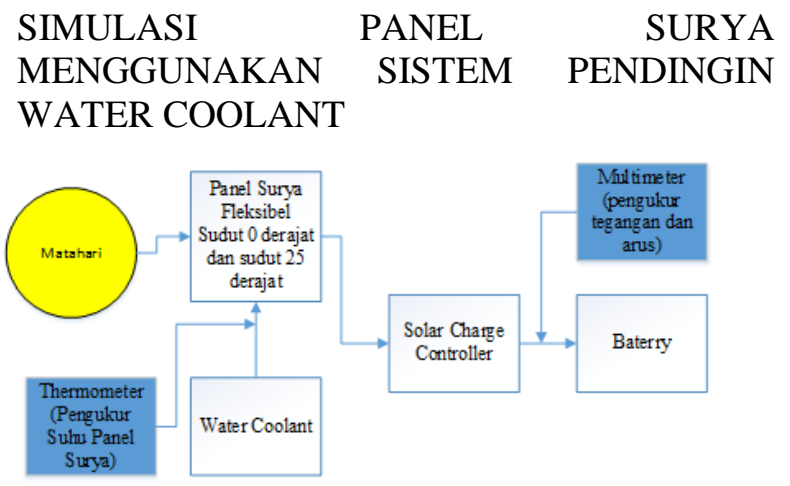

Gambar 2 Simulasi panel surya menggunakan pendingin water coolant.

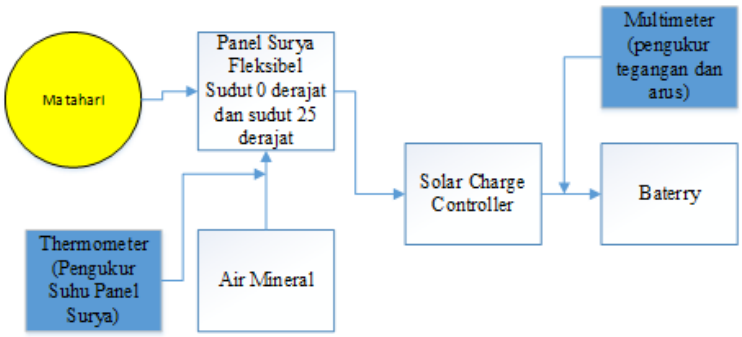

Gambar 3 Simulasi panel surya menggunakan pendingin air mineral.

\section{SIMULASI \\ PANEL \\ SURYA \\ MENGGUNAKAN SISTEM PENDINGIN AIR LAUT}

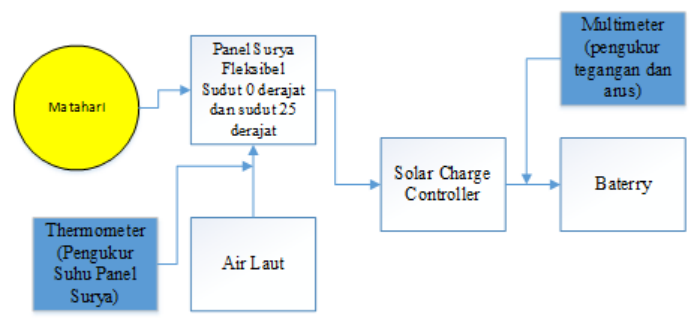

Gambar 4 Simulasi panel surya menggunakan pendingin air laut.

\section{HASIL DAN ANALISA}

Hasil dan Pembahasan di sini akan menjelaskan tentang pengujian alat dan hasil dari pengujian tersebut. Pengujian alat dalam penelitian ini adalah pengujian yang dilakukan pada panel surya di uji menggunakan penyinaran matahari. Tujuan dari proses pengujian adalah untuk mengetahui karakteristik dan output yang dihasilkan oleh panel surya Fleksibel menggunakan water coolant, air mineral, dan air laut. Pengujian dilakukan dengan cara mengambil data - data output dari penelitian yang digunakan untuk mengetahui perbandingan karakteristik dan output yang dihasilkan oleh panel surya.

\section{TUJUAN PENGUJIAN}

Pengujian dilakukan dengan tujuan untuk mengetahui karakteristik, output yang dihasilkan, dan perbandingan output daya yang dihasilkan panel surya Fleksibel menggunakan system pendingin water coolant, air mineral, dan air laut pada saat pencahayaan matahari secara langsung.

\section{TARGET PENGUJIAN}

Menguji perbedaan karakteristik dan perbedaan output antara Panel Surya Fleksibel menggunakan pendingin water coolant, air mineral, dan air laut dengan menggunakan pencahayaan matahari secara langsung. 
RESISTOR (Elektronika Kendali Telekomunikasi Tenaga Listrik Komputer) Vol. 2 No. 2 e-ISSN : 2621-9700, p-ISSN : 2654-2684

\section{ILUSTRASI PENGAMBILAN DATA TEMPERATUR PANEL SURYA FLEKSIBEL}

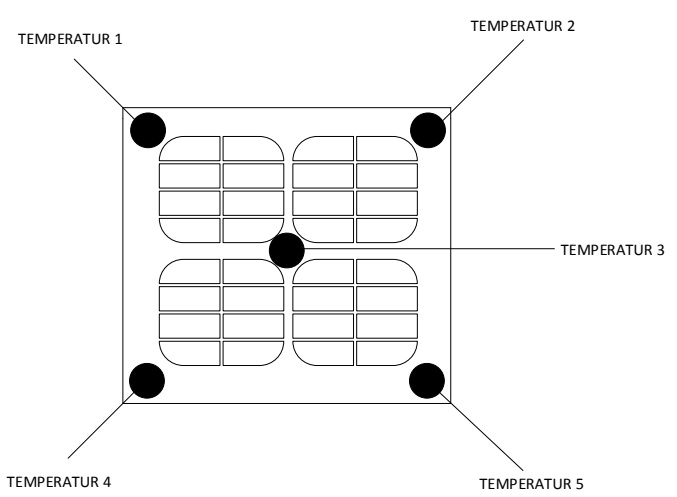

Gambar 5 Ilustrasi pengambilan temperatur panel surya fleksibel.

ILUSTRASI PENGAMBILAN DATA SISTEM PENDINGIN PANEL SURYA FLEKSIBEL

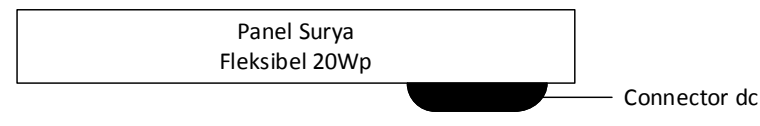

Water Coolant, Air Laut, Air Mineral

Gambar 6 Ilustrasi pengambilan data sistem panel surya fleksibel.

PENGUJIAN PANEL SURYA FLEKSIBEL SISTEM PENDINGIN WATER COOLANT DENGAN SUDUT 0 DERAJAT

Tabel 1 Pengujian sistem pendingin water coolant.

\begin{tabular}{|c|c|c|c|c|c|}
\hline \multicolumn{6}{|c|}{$\begin{array}{c}\text { PENGUJIAN PANEL SURYA FLEKSIBEL PADA SISTEM } \\
\text { PENDINGIN WATER COOLANT DENGAN SUDUT } 0 \\
\text { DERAJAT }\end{array}$} \\
\hline Waktu & $\begin{array}{l}\text { Intensitas } \\
\text { Cahaya } \\
\left(\mathrm{W} / \mathrm{m}^{2}\right)\end{array}$ & $\begin{array}{l}\text { Tegangan } \\
\text { (V) }\end{array}$ & $\begin{array}{l}\text { Arus } \\
\text { (A) }\end{array}$ & $\begin{array}{l}\text { Daya } \\
\text { (W) }\end{array}$ & $\begin{array}{c}\text { efisiensi } \\
(\%)\end{array}$ \\
\hline 09.00 & 658 & 19,71 & 0,73 & 14,39 & $15,41 \%$ \\
\hline 09.30 & & & 0,69 & 13,57 & \\
\hline 10.0 & & & 0,67 & 13,13 & \\
\hline 10.30 & 734 & 19,48 & 0,65 & 12,66 & $12,16 \%$ \\
\hline 11.00 & 762 & 19,4 & 0,64 & 12,42 & $11,48 \%$ \\
\hline 11.30 & & & 0,59 & 11,46 & \\
\hline 12.00 & 792 & 19,38 & 0,6 & 11,63 & $10,35 \%$ \\
\hline & & & 0,54 & & \\
\hline 13.00 & 764 & 19,21 & 0,56 & 10,76 & $9,92 \%$ \\
\hline 13.30 & & & 0,58 & 10,99 & $10,42 \%$ \\
\hline & & & 0,62 & 11,76 & \\
\hline 14.30 & 705 & 19,05 & 0,64 & 12,19 & $12,19 \%$ \\
\hline 15.00 & 692 & 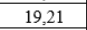 & 0,65 & 12,49 & $12,72 \%$ \\
\hline 15.30 & & & 0,62 & 12,00 & $13,97 \%$ \\
\hline 16.00 & 590 & 19,41 & 0,64 & 12,42 & $14,84 \%$ \\
\hline & 718,93 & 19,34 & 0,63 & 12,15 & $12,03 \%$ \\
\hline
\end{tabular}

Rumus perhitungan efisiensi:

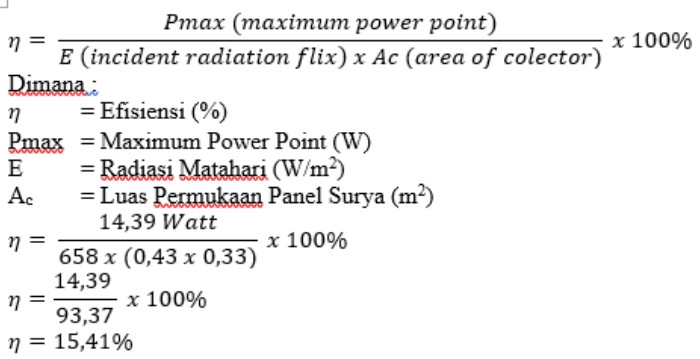

PENGUJIAN PANEL SURYA FLEKSIBEL SISTEM PENDINGIN AIR MINERAL DENGAN SUDUT 0 DERAJAT

Tabel 2 Pengujian sistem pendingin air mineral.

\begin{tabular}{|c|c|c|c|c|c|}
\hline \multicolumn{6}{|c|}{$\begin{array}{l}\text { PENGUJIAN PANEL SURYA FLEKSIBEL PADA SISTEM } \\
\text { PENDINGIN AIR MINERAL DENGAN SUDUT 0 } \\
\text { DERAJAT }\end{array}$} \\
\hline Waktu & $\begin{array}{l}\text { Intensitas } \\
\text { Cahaya } \\
\left(\mathrm{W} / \mathrm{m}^{2}\right)\end{array}$ & $\begin{array}{l}\text { Tegangan } \\
\text { (V) }\end{array}$ & $\begin{array}{l}\text { Arus } \\
\text { (A) }\end{array}$ & $\begin{array}{c}\text { Daya } \\
\text { (W) }\end{array}$ & $\begin{array}{c}\text { efisiensi } \\
(\%)\end{array}$ \\
\hline 09.00 & 658 & 19,55 & 0,69 & 13,49 & $14,45 \%$ \\
\hline 09.30 & 720 & 19,43 & 0,65 & 12,63 & $12,36 \%$ \\
\hline 10.00 & 740 & 19,39 & 0,64 & 12,41 & $11,82 \%$ \\
\hline 10.30 & 734 & 19,28 & 0,62 & 11,95 & $11,48 \%$ \\
\hline 11.00 & 762 & 19,24 & 0,6 & 11,54 & $10,68 \%$ \\
\hline 11.30 & 775 & 19,22 & 0,58 & 11,15 & $10,14 \%$ \\
\hline 12.00 & 792 & 19,18 & 0,57 & 10,93 & $9,73 \%$ \\
\hline 12.30 & 784 & 19,16 & 0,54 & 10,35 & $9,30 \%$ \\
\hline 13.00 & 764 & 19,1 & 0,55 & 10,51 & $9,69 \%$ \\
\hline 13.30 & 743 & 18,78 & 0,56 & 10,52 & $9,97 \%$ \\
\hline 14.00 & 720 & 18,67 & 0,57 & 10,64 & $10,42 \%$ \\
\hline 14.30 & 705 & 18,89 & 0,59 & 11,15 & $11,14 \%$ \\
\hline 15.00 & 692 & 19,05 & 0,62 & 11,81 & $12,03 \%$ \\
\hline 15.30 & 605 & 19,25 & 0,59 & 11,36 & $13,23 \%$ \\
\hline 16.00 & 590 & 19,3 & 0,61 & 11,77 & $14,06 \%$ \\
\hline $\begin{array}{c}\text { Rata - } \\
\text { Rata }\end{array}$ & 718,93 & 19,17 & 0,60 & 11,48 & $11,37 \%$ \\
\hline
\end{tabular}

Rumus perhitungan efisiensi:

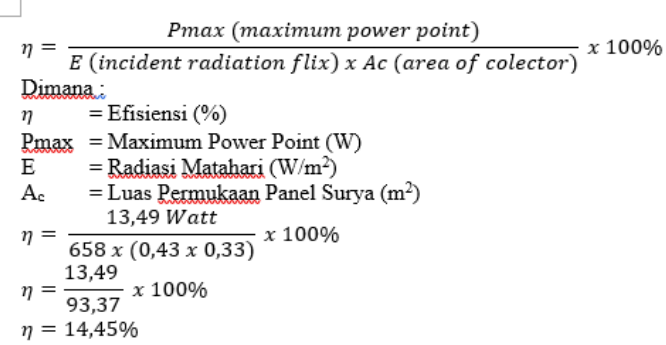

PENGUJIAN PANEL SURYA FLEKSIBEL SISTEM PENDINGIN AIR LAUT DENGAN SUDUT 0 DERAJAT

Tabel 3 Pengujian sistem pendingin air laut. 
RESISTOR (Elektronika Kendali Telekomunikasi Tenaga Listrik Komputer) Vol. 2 No. 2 e-ISSN : 2621-9700, p-ISSN : 2654-2684

\begin{tabular}{|c|c|c|c|c|c|}
\hline \multicolumn{6}{|c|}{$\begin{array}{l}\text { PENGUJIAN PANEL SURYA FLEKSIBEL PADA } \\
\text { SISTEM PENDINGIN AIR LAUT DENGAN SUDUT } 0 \\
\text { DERAJAT }\end{array}$} \\
\hline Waktu & $\begin{array}{l}\text { Intensitas } \\
\text { Cahaya } \\
\left(\mathrm{W} / \mathrm{m}^{2}\right)\end{array}$ & $\begin{array}{l}\text { Tegangan } \\
\text { (V) }\end{array}$ & $\begin{array}{l}\text { Arus } \\
\text { (A) }\end{array}$ & $\begin{array}{l}\text { Daya } \\
\text { (W) }\end{array}$ & $\begin{array}{l}\text { efisiensi } \\
(\%)\end{array}$ \\
\hline 09.00 & 658 & 19,39 & 0,65 & 12,60 & $13,50 \%$ \\
\hline 09.30 & 720 & 19,3 & 0,63 & 12,16 & $11,90 \%$ \\
\hline 10.00 & 740 & 19,29 & 0,61 & 11,77 & $11,21 \%$ \\
\hline 10.30 & 734 & 19,21 & 0,59 & 11,33 & $10,88 \%$ \\
\hline 11.00 & 762 & 19,14 & 0,58 & 11,10 & $10,27 \%$ \\
\hline 11.30 & 775 & 19,12 & 0,55 & 10,52 & $9,56 \%$ \\
\hline 12.00 & 792 & 19,08 & 0,54 & 10,30 & $9,17 \%$ \\
\hline 12.30 & 784 & 19,06 & 0,52 & 9,91 & $8,91 \%$ \\
\hline 13.00 & 764 & 18,95 & 0,53 & 10,04 & $9,26 \%$ \\
\hline 13.30 & 743 & 18,62 & 0,54 & 10,05 & $9,54 \%$ \\
\hline 14.00 & 720 & 18,47 & 0,55 & 10,16 & $9,94 \%$ \\
\hline 14.30 & 705 & 18,78 & 0,56 & 10,52 & $10,51 \%$ \\
\hline 15.00 & 692 & 18,98 & 0,6 & 11,39 & $11,60 \%$ \\
\hline 15.30 & 605 & 19,11 & 0,58 & 11,08 & $12,91 \%$ \\
\hline 16.00 & 590 & 19,2 & 0,59 & 11,33 & $13,53 \%$ \\
\hline $\begin{array}{l}\text { Rata - } \\
\text { Rata }\end{array}$ & 718,93 & 19,05 & 0,57 & 10,95 & $10,85 \%$ \\
\hline
\end{tabular}

Rumus perhitungan efisiensi:

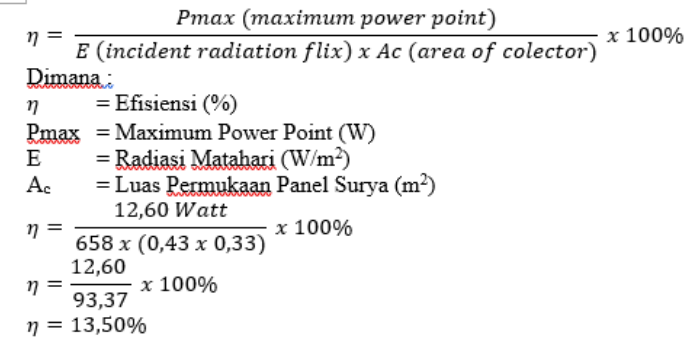

GRAFIK HASIL PENGUJIAN SISTEM PENDINGIN PANEL SURYA FLEKSIBEL

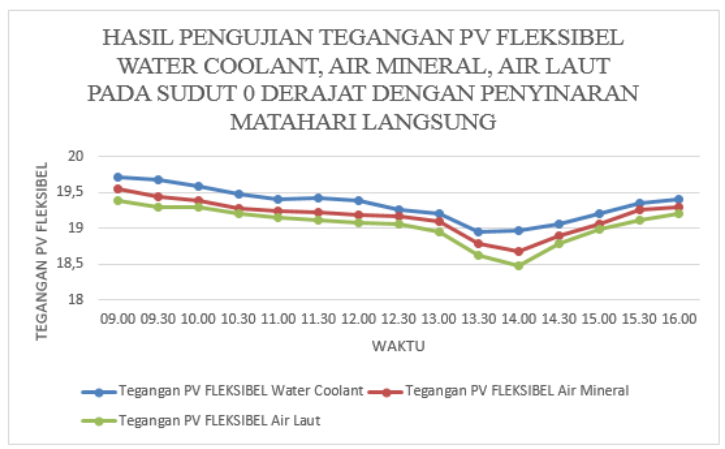

Gambar 7 Hasil pengujian tegangan panel surya fleksibel menggunakan sistem pendingin water coolant, air mineral, dan air laut dengan sudut 0 derajat.

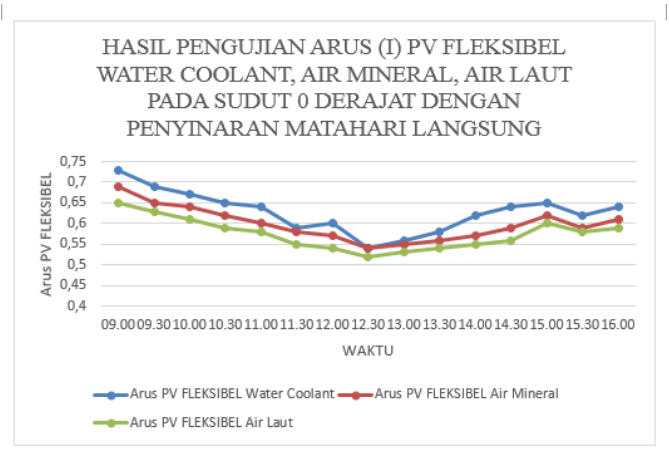

Gambar 8 Hasil pengujian arus panel surya fleksibel menggunakan sistem pendingin water coolant, air mineral, dan air laut dengan sudut 0 derajat.

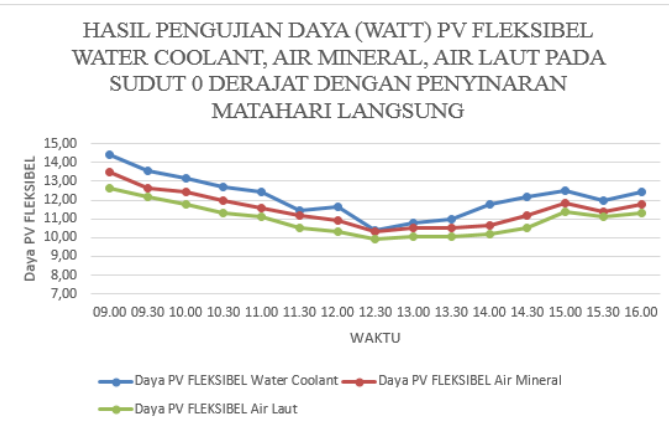

Gambar 9 Hasil pengujian daya panel surya fleksibel menggunakan sistem pendingin water coolant, air mineral, dan air laut dengan sudut 0 derajat.

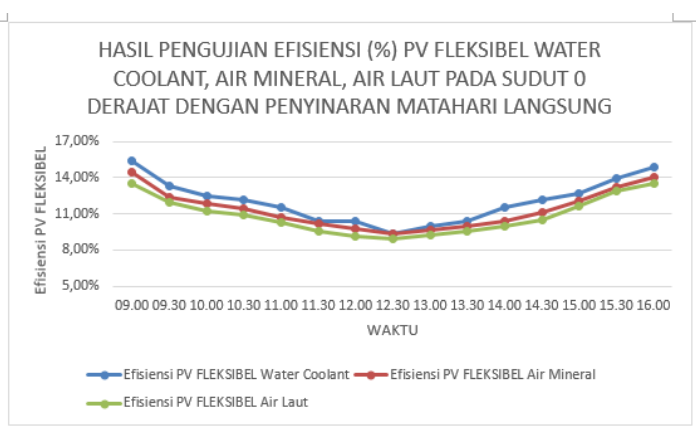

Gambar 10 Hasil pengujian efisiensi panel surya fleksibel menggunakan sistem pendingin water coolant, air mineral, dan air laut dengan sudut 0 derajat.

\section{HASIL PENGUJIAN SISTEM PENDINGIN PANEL SURYA FLEKSIBEL PADA SUDUT 25 DERAJAT}

Tabel 4 Pengujian panel surya fleksibel system pendingin water coolant pada sudut 25 derajat. 
RESISTOR (Elektronika Kendali Telekomunikasi Tenaga Listrik Komputer) Vol. 2 No. 2 e-ISSN : 2621-9700, p-ISSN : 2654-2684

coolant, air mineral, dan air laut dengan sudut 25 derajat.

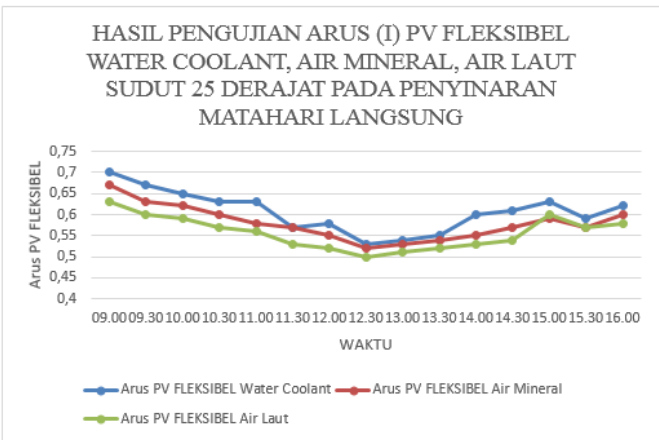

Gambar 12 Hasil pengujian arus panel surya fleksibel menggunakan sistem pendingin water coolant, air mineral, dan air laut dengan sudut 25 derajat.

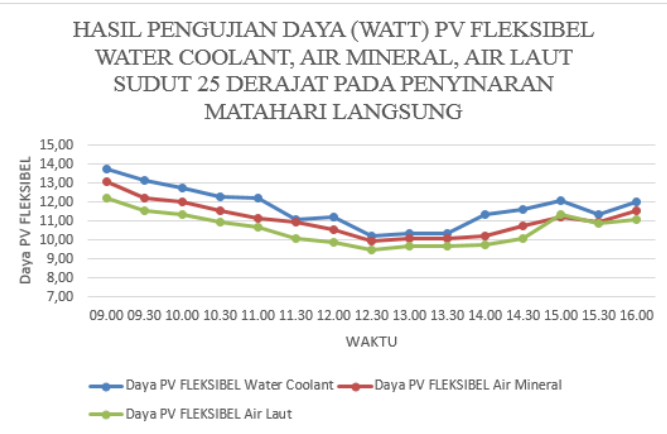

Gambar 13 Hasil pengujian daya panel surya fleksibel menggunakan sistem pendingin water coolant, air mineral, dan air laut dengan sudut 25 derajat.

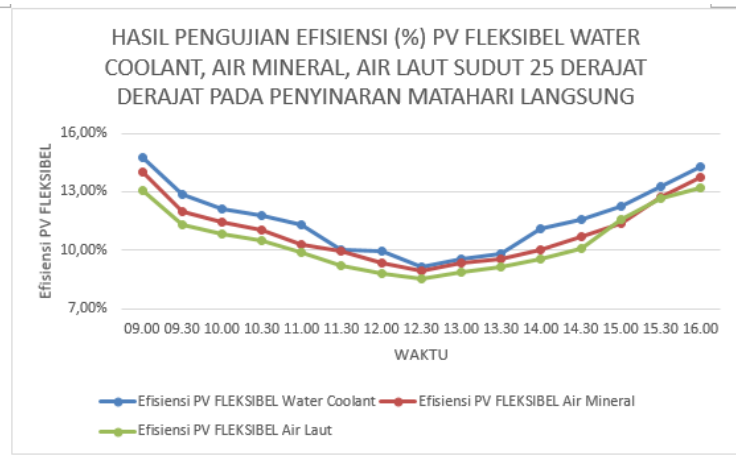

Gambar 14 Hasil pengujian efisiensi panel surya fleksibel menggunakan sistem pendingin water coolant, air mineral, dan air laut dengan sudut 25 derajat.

\section{KESIMPULAN}

Dari hasil pengujian dan Analisa pada saat pencahayaan matahari langsung Panel Surya Fleksibel dengan sudut 0 Derajat menggunakan system pendingin panel surya water coolant di dapatkan hasil efisiensi sebesar 15.41\%, Panel Surya Fleksibel menggunakan system pendingin air mineral didapatkan hasil efisiensi sebesar $14.45 \%$, dan panel surya system pendingin air laut didapatkan efisiensi sebesar $13.50 \%$.

Dari hasil pengujian dan Analisa pada saat pencahayaan matahari langsung Panel Surya Fleksibel dengan sudut 25 Derajat menggunakan system pendingin panel surya water coolant di dapatkan hasil efisiensi sebesar 14.74\%, panel surya menggunakan system pendingin air mineral didapatkan hasil efisiensi sebesar $14.01 \%$, dan panel surya system pendingin air laut didapatkan efisiensi sebesar $13.06 \%$

Dari hasil pengujian dan Analisa pada saat pencahayaan matahari langsung Panel Surya Fleksibel menggunakan system pendingin water coolant mendapatkan hasil yang lebih baik dibandingkan dengan air mineral, dan air laut. Sedangkan dari sisi derajat Panel Surya Fleksibel pada posisi 0 derajat mendapatkan hasil yg lebih baik.

Dari hasil pengujian dan Analisa pada saat pencahayaan matahari langsung panel surya menggunakan system pendingin water coolant mengalami penurunan suhu permukaan panel pada temperature 1, temperature 2, temperature 3, temperature 4 , dan temperature 5 dibandingkan suhu permukaan panel menggunakan system pendingin air mineral, dan air laut.

\section{DAFTAR PUSTAKA}

[1] D. Suryana, "Pengaruh temperatur/suhu terhadap tegangan yang dihasilkan panel surya jenis monokristalin (studi kasus: Baristand Industri Surabaya),” Jurnal Teknologi Proses dan Inovasi Industri, vol. 1, no. 2, 2016.

[2] J. L. Cruz-Campa et al., "Ultrathin flexible crystalline silicon: Microsystems-enabled photovoltaics," IEEE journal of Photovoltaics, vol. 1, no. 1, pp. 3-8, 2011.

[3] M. Pagliaro, R. Ciriminna, and G. Palmisano, "Flexible solar cells," ChemSusChem: Chemistry \& Sustainability Energy \& Materials, vol. 1, no. 11, pp. 880-891, 2008.

[4] T. Damas Setyo, "Rancang Bangun Sistem Penangkapan Energi Maksimum Pada Solar Cell,” Universitas Indonesia, 2009. 
RESISTOR (Elektronika Kendali Telekomunikasi Tenaga Listrik Komputer) Vol. 2 No. 2 e-ISSN : 2621-9700, p-ISSN : 2654-2684

[5] K. Trautz et al., "High efficiency flexible solar panels," in 2013 IEEE 39th Photovoltaic Specialists Conference (PVSC), 2013, pp. 0115-0119.

[6] K.-H. Tsai et al., "High efficiency of flexible polymer solar cell based on poly (3hexylthiophene)/fullerene," in 2009 34th IEEE Photovoltaic Specialists Conference (PVSC), 2009, pp. 001678-001680.

[7] A. Afriandi, "Implementasi Water Cooling System Untuk Menurunkan Temperature Losses Pada Panel Surya," Jurnal Teknik Elektro Universitas Tanjungpura, vol. 2, no. 1.

[8] H. Muchtar and R. Apriadi, "Implementasi Pengenalan Wajah Pada Sistem Penguncian Rumah Dengan Metode Template Matching Menggunakan Open Source Computer Vision Library (Opencv)," RESISTOR (elektRonika kEndali telekomunikaSI tenaga liSTrik kOmputeR), vol. 2, no. 1, pp. 39-42, 2019.

[9] P. G. Chamdareno and H. Hilal, "Analisa Pembangkit Listrik Tenaga Hybrid PLTDPLTS di Pulau Tunda Serang Banten,” RESISTOR (elektRonika kEndali telekomunikaSI tenaga liSTrik kOmputeR), vol. 1, no. 1, pp. 35-42, 2018.

[10] P. G. Chamdareno, E. Nuryanto, and E. Dermawan, "Perencanaan Sistem Pembangkit Listrik Hybrid (Panel Surya dan Diesel Generator) pada Kapal KM. Kelud,” RESISTOR (elektRonika kEndali telekomunikaSI tenaga liSTrik kOmputeR), vol. 2, no. 1, pp. 59-64, 2019.

[11] H. Isyanto and D. Arsito, "Sistem Pengaman Rumah dan Peringatan Dini Kebakaran Berbasis SMS dengan Menggunakan Raspberry Pi,” RESISTOR (elektRonika kEndali telekomunikaSI tenaga liSTrik kOmputeR), vol. 1, no. 1, pp. 13-24, 2018.

[12] S. Sriyono and B. Budiyanto, "Studi Penggunaan DC Nanogrid dengan Sumber Photovoltaic pada Beban Bertegangan dibawah Dua Puluh Empat Volt," RESISTOR (elektRonika kEndali telekomunikaSI tenaga liSTrik kOmputeR), vol. 2, no. 1, pp. 1-6, 2019.

[13] F. Fadliondi, P. G. Chamdareno, and H. Isyanto, "Perbandingan Pemahaman tentang Instalasi Listrik Rumah Tinggal antara Sebelum dan Sesudah Mengikuti Pelatihan,” Jurnal Pengabdian Masyarakat Teknik, vol. 1, no. 1, pp. 1-11, 2018.

[14] F. Fadliondi, H. Isyanto, and P. Gagani, "Pengaruh Ketebalan Lapisan Isolator Sio2 terhadap Mobilitas Lubang dari Transistor Efek Medan Organik Pentacene,” Prosiding Semnastek, 2016.

[15] H. Muchtar and R. Sumanjaya, "Control Switch Otomatis pada Tegangan Energi Alternatif dan Tegangan Sumber PLN Menggunakan Raspberry Pi,” RESISTOR (elektRonika $k$ Endali telekomunikaSI tenaga liSTrik kOmputeR), vol. 1, no. 2, 2018.

[16] F. Fadliondi, B. Budiyanto, and H. Isyanto, "SIMULASI KARAKTERISTIK LISTRIK DARI SEL SURYA YANG TERHUBUNG SECARA PARALEL DAN PENGUJIANNYA SECARA EKSPERIMEN,” Prosiding Semnastek, 2018.

[17] M. H. Widianto, “Alat Pengatur Suhu Otomatis pada Ruangan Produksi Textile Spining Berbasis Mikrokontroler Atmega32 di PT. San Star Manunggal,” RESISTOR (elektRonika kEndali telekomunikaSI tenaga liSTrik kOmputeR), vol. 2, no. 1, pp. 51-58, 2019.

[18] R. Samsinar and W. Wiyono, "Studi Keandalan Rekonfigurasi Jaringan Program Zero Down Time (Zdt) di Kawasan Sudirman Central Business Distric (Scbd) Menggunakan Software ETAP 12.6,” RESISTOR (elektRonika kEndali telekomunikaSI tenaga liSTrik kOmputeR), vol. 2, no. 1, pp. 65-72, 2019.

[19] F. Fadliondi and A. Asriyadi, "Eksperimen dan Simulasi Rangkaian Band Pass Filter (BPF) dengan Resistor dan Kapasitor,” RESISTOR (elektRonika kEndali telekomunikaSI tenaga liSTrik kOmputeR), vol. 1, no. 2, pp. 69-78, 2018.

[20] F. Fadliondi, N. Hasanah, and A. Asriyadi, "Simulasi dan Pembuatan Rangkaian Penyearah Gelombang Penuh dengan Trafo Center Tapped dengan Memakai Perangkat Lunak LT SPICE,” RESISTOR (elektRonika kEndali telekomunikaSI tenaga liSTrik kOmputeR), vol. 2, no. 1, pp. 23-28, 2019.

[21] P. G. Chamdareno, B. Budiyanto, F. Fadliondi, and $\mathrm{H}$. Isyanto, "STUDI EKSPERIMEN TERHADAP PANEL SURYA DAN INVERTER,” Prosiding Semnastek, 2017.

[22] B. Budiyanto and F. Fadliondi, "The Improvement of Solar Cell Output Power Using Cooling and Reflection from Mirror," 
RESISTOR (Elektronika Kendali Telekomunikasi Tenaga Listrik Komputer) Vol. 2 No. 2 e-ISSN : 2621-9700, p-ISSN : 2654-2684

International Journal of Power Electronics and Drive Systems, vol. 8, no. 3, p. 1320, 2017.

[23] F. Fadliondi, H. Isyanto, and P. G. Chamdareno, "The comparison of organic field effect transistor (OFET) structures,” in 2017 2nd International Conference on Frontiers of Sensors Technologies (ICFST), 2017, pp. 6-9.

[24] H. Isyanto and M. Syahrullah, "Perancangan Security Home (Keamanan pada Rumah) Menggunakan Mikrokontroller Berbasis SMS (Short Message Service)," RESISTOR (elektRonika kEndali telekomunikaSI tenaga liSTrik kOmputeR), vol. 1, no. 2, pp. 85-96, 2018.

[25] M. H. Widianto, "Pengaplikasian Sensor Hujan dan LDR untuk Lampu Mobil Otomatis Berbasis Arduino Uno,” RESISTOR (elektRonika kEndali telekomunikaSI tenaga liSTrik kOmputeR), vol. 1, no. 2, 2018.

[26] H. Isyanto, F. Fadliondi, and A. Aprinol, "SIMULASI STUDI SISTEM TRAFFIC LIGHT TERINTEGRASI PADA PERLINTASAN KERETA API," eLEKTUM, vol. 13, no. 2, pp. 26-35, 2017.

[27] H. Isyanto, B. Budiyanto, F. Fadliondi, and P. G. Chamdareno, "Pendingin Untuk Peningkatan Daya Keluaran Panel Surya," Prosiding Semnastek, 2017.

[28] F. Fadliondi and B. Budiyanto, "Transistor Efek Medan Berbasis Semikonduktor Organik Pentacene untuk Sensor Kelembaban,” Jurnal Nasional Teknik Elektro dan Teknologi Informasi, vol. 6, no. 2, pp. 204-209, 2017.

[29] E. B. Prasetya, “Aplikasi Manajemen Proyek Konstruksi dengan Metode Critical Path dan Earned Value Management," RESISTOR (elektRonika kEndali telekomunikaSI tenaga liSTrik kOmputeR), vol. 1, no. 2, pp. 53-68, 2018.

[30] F. Fadliondi, M. Kunta Biddinika, and S. I. Omi, "The Humidity Dependence of Pentacene Organic Metal-Oxide-Semiconductor FieldEffect Transistor.," Telkomnika, vol. 15, no. 2, 2017.

[31] F. Fadliondi, H. Isyanto, and B. Budiyanto, "Bypass Diodes for Improving Solar Panel Performance," International Journal of Electrical and Computer Engineering, vol. 8, no. 5, p. 2703, 2018.
[32] H. Isyanto, A. Solikhin, and W. Ibrahim, "Perancangan dan Implementasi Security System pada Sepeda Motor Menggunakan RFID Sensor Berbasis Raspberry Pi," RESISTOR (elektRonika kEndali telekomunikaSI tenaga liSTrik kOmputeR), vol. 2, no. 1, pp. 29-38, 2019.

[33] L. Halim and C. F. Naa, "Desain Sistem Pendayaan Energi Listrik pada Rumah Kaca Pintar dengan Menggunakan Pembangkit Listrik Tenaga Surya,” RESISTOR (elektRonika kEndali telekomunikaSI tenaga liSTrik kOmputeR), vol. 2, no. 1, pp. 43-50, 2019. 
RESISTOR (Elektronika Kendali Telekomunikasi Tenaga Listrik Komputer) Vol. 2 No. 2 e-ISSN : 2621-9700, p-ISSN : 2654-2684 